\title{
Analysis of possible food/nutrient and drug interactions in hospitalized patients
}

\author{
Análise das possíveis interações entre medicamentos e alimento/nutrientes \\ em pacientes hospitalizados
}

\author{
Everton Moraes Lopes ${ }^{1}$, Rumão Batista Nunes de Carvalho², Rivelilson Mendes de Freitas ${ }^{3}$
}

\begin{abstract}
Objective: To evaluate the prescription in relation to the possible interactions between drugs and foods/nutrients in the diets of patients in the Hospital Regional Justino Luz in the municipality of Picos, Piauí, Brazil. Methods: The sample consisted of 60 medical records of patients admitted at the hospital. The records were analyzed according to the presence or absence of interactions between drugs and foods/nutrients of the prescribed diets. Results: Of the 82 drugs prescribed in all periods, there were 16 drugs $(19.5 \%)$ with possible interaction with food, a total of 60 interactions between nutrient/ food and medicine. Thus, $18(30 \%), 10(17 \%)$ and $8(13 \%)$ possible interactions were identified with captopril (cardiovascular drug) with acetylsalicylic acid (anti-inflammatory) and spironolactone (diuretic), respectively representing the highest numbers of interactions among the classes of investigated drugs. It was also found that the total interactions between food/nutrients and drugs, $32(53 \%)$ accounted for interactions with cardiovascular drugs, $13(22 \%)$ with antiinflammatory drugs, $11(18 \%)$ with diuretic agents e $4(7 \%)$ with drugs that act on the digestive tract. Conclusion: There was a high number of interactions between food/nutrients and medicines emphasizing the need for prior knowledge of these interactions as a way to avoid impairment in the treatment, longer hospital stays and/or damage to the nutritional status of the patients.
\end{abstract}

Keywords: Food-drug interactions; Nutrients; Biochemical phenomena; Hospitalization; Medical records

\section{RESUMO}

Objetivos: Avaliar as possíveis interações entre os medicamentos e os alimentos/nutrientes das dietas de pacientes do Hospital Regional Justino Luz do município de Picos, Piauí. Métodos: A amostra foi constituída por 60 prontuários médicos de pacientes internados analisados para verificar a presença ou não de interações entre os medicamentos e os alimentos/nutrientes das dietas prescritas.
Resultados: Dos 82 medicamentos prescritos, em todos os períodos, havia $16(19,5 \%)$ com possível interação com a alimentação, totalizando 60 interações entre nutriente/alimentos e medicamentos. Assim, foram identificadas $18(30 \%), 10(17 \%)$ e 8 (13\%) possíveis interações com 0 captopril (droga cardiovascular), com 0 ácido acetilsalićlico (anti-inflamatório) e com a espironolactona (diurético), respectivamente, representando as maiores frequências de interações entre as classes farmacológicas investigadas. Detectouse também que, do total das interações entre alimentos/nutrientes e medicamentos, $32(53 \%)$ corresponderam a interações com drogas cardiovasculares; $13(22 \%)$ com fármacos anti-inflamatórios, 11 (18\%) com agentes diuréticos e $4(7 \%)$ com fármacos que atuam sobre 0 trato digestório. Conclusão: Verificou-se um alto número de interações entre alimentos/nutrientes e medicamentos, reforçando a necessidade do conhecimento prévio dessas interações para que não haja prejuízo no tratamento, aumento do tempo de internação e/ou danos ao estado nutricional dos pacientes.

Descritores: Interações alimento-droga; Nutrientes; Fenômenos bioquímicos; Hospitalização; Registros médicos

\section{INTRODUCTION}

Satisfactory and healthy maintenance of the body requires nutrients that are essential and supply energy. Varied diets in amounts that are continually regulated provide energy, assure performance and functioning of the body, in addition to tissue differentiation and defense mechanisms ${ }^{(1)}$.

Many pathological processes demand an appropriate food intake and administration of efficient and safe drugs $^{(2)}$. However, the association between drugs and nutrients may lead to undesirable interactions, resulting in increased or reduced efficacy of the drug and/or

\footnotetext{
Study carried out at Hospital Regional Justino Luz - HRJL, Picos (PI), Brazil.

${ }^{1}$ Nursing student at Universidade Federal do Piauí - UFPI, Picos (PI), Brazil.

${ }^{2}$ Nursing student at Universidade Federal do Piauí - UFPI, Picos (PI), Brazil.

${ }^{3}$ Adjunct Professor of Pharmacology at Universidade Federal do Piauí - UFPI, Picos (PI), Brazil.

Corresponding author: Rivelilson Mendes de Freitas - Rua Cícero Eduardo, s/n, Junco - CEP 64600-000 - Picos (PI), Brazil - e-mail: rivelilson@pq.cnpq.br

Received on: Feb 26, 2010 - Accepted on: Jun 09, 2010
} 
nutrient ${ }^{(3)}$. Drug-food interaction is considered when a food or nutrient alters the efficacy of a medication, or when a drug interferes in the nutritional status of the individual. Hence, not only drugs but also some foods and nutrients can hinder absorption, but some foods and nutrients can hamper the action of medicines ${ }^{(4)}$.

The food-drug interaction is defined as change in kinetics or dynamics of a medication or nutrient, or as impairment of nutritional status resulting from administration of a medicine. Pharmacokinetics is understood as the quantitative description of a medication or its availability, including absorption, distribution, metabolism and excretion. Pharmacodynamics is characterized by the clinical or physiological effect of the medication ${ }^{(4,5)}$.

Most drugs and nutrients are absorbed in the small bowel. The drug-nutrient interactions may alter this absorption by reducing emptying time of the digestive system through formation of chelates, originated from reactions between metallic cations - present in the matrix of foods - and drugs, due to their physical and chemical characteristics, as well as by changes in absorption of fats, fat-soluble vitamins and cholesterol due to lesions produced in the intestinal mucosa ${ }^{(6)}$.

Drug-nutrient interaction can also occur in the pharmacokinetic phase of plasma distribution. Some studies demonstrated that binding of a drug to a plasma protein can be modified by a diet rich in $\mathrm{fat}^{(7)}$. The changes in the metabolism of drugs are often related to enzyme inhibition or by formation of insoluble complexes with nutrients. Some drugs can increase or decrease the renal excretion of certain nutrients through glomerular filtration, interfering in renal reabsorption of nutrients ${ }^{(7)}$.

These possible interactions can hinder the action of the drug and/or food, and result in prolonged use of medications in chronic treatments or malnutrition, increased costs and longer hospital stay.

\section{OBJECTIVE}

To evaluate the possible interactions between drugs and foods/nutrients of the diets of hospitalized patients.

\section{METHODS}

\section{Setting}

The data was collected at the care units of the Hospital Regional Justino Luz (HRJL), a 120-bed secondarycare and reference hospital, financed by the Single Health System (SUS, acronym in Portuguese), which also provides emergency care in the city of Picos, State of Piauí, from August 2009 to January 2010.

\section{Data collection and independent variables}

Data collection in medical records through direct consultation was performed by Nursing undergraduate students of Universidade Federal do Piauí, who were trained under supervision. A standardized and validated questionnaire was filled out while looking through the records to collect the following data: age, skin color mentioned by the patient, health problems, presumptive diagnoses, administered medications and the prescribed diets.

\section{Study design}

The interviews were based on the methodology proposed by Cipolle et al. ${ }^{(8)}$ The results were obtained through an exploratory quantitative study, with direct observation by analysis of 60 medical records and diets prescribed for inpatients at the HRJL. All records during the study period were included, considering they were on at least one medication administered by oral route for clinical treatment and accepted and signed the free and informed consent form to voluntarily take part in the project. In order to avoid any methodological bias, the following patients were excluded: those at risk, in emergency-room and the individuals who did not receive any oral medications during hospital stay.

\section{Ethical considerations}

The study was approved by the Technical Administrative Board of the HRJL. The undergraduate students were authorized to collect data for prescription and data analyses, by patients who signed the free and informed consent form. There was no identification by name, neither any moral risk to patients, considering the purpose of dealing with only statistical data.

The research protocol complied with the ethical principles of the Declaration of Helsinki and the norms of the resolution n. 196/96 of the National Health Council was approved by the Research Ethics Committee of Universidade Federal do Piauí (CAAE 0099.0.045.000-09).

\section{RESULTS}

Although the results of this study present some limitations due to quality of information recorded in the charts hindering analysis, these data may represent the possible interaction between foods/nutrients and medications prescribed to patients admitted to this SUS service in Piauí. Out of 60 patients considered for chart analysis, $88.3 \%$ were aged over 41 years and $11.7 \%$ were 15 to 40 years. As to skin color, 88.4, 8.3 and 3.3\% 
Table 1. Analysis of possible interactions between foods/nutrients and drugs prescribed in medical charts of inpatients

\begin{tabular}{|c|c|c|c|c|}
\hline Drugs & Foods/nutrients & Mechanisms/effects & Recommendations & $\begin{array}{l}\text { Number of cases of } \\
\text { possible interactions }\end{array}$ \\
\hline \multicolumn{5}{|l|}{ Cardiovascular } \\
\hline Amiloride & Calcium (milk and cheese) & $\begin{array}{l}\text { Decreases absorption of calcium } \\
\text { (Ca) }\end{array}$ & To avoid administration with calcium-rich foods & 1 \\
\hline Captopril & Foods in general & Decrease absorption of the drug & To give one hour before or two hours after meals & 18 \\
\hline Carvedilol & Foods in general & $\begin{array}{l}\text { Administered with foods, decreases } \\
\text { orthostatic hypertension }\end{array}$ & To administer with foods & 6 \\
\hline Digoxin & Carrot (fibers) & Decreases absorption of the drug & To avoid administration with foods rich in fibers & 4 \\
\hline Nifedipine & Foods in general & Increase bioavailability of the drug & To administer with foods & 2 \\
\hline Propanolol & Milk (proteins) & Increases bioavailability of the drug & To administer with foods high in protein & 1 \\
\hline \multicolumn{5}{|l|}{ Anti-inflammatory } \\
\hline Acetylsalicylic acid & $\begin{array}{l}\text { Passion fruit juice (vitamin } \mathrm{C} \text { ) and } \\
\text { lettuce (vitamin } \mathrm{K} \text { ) }\end{array}$ & Deplete absorption of the vitamins & $\begin{array}{l}\text { Do not eat foods rich in vitamins } \mathrm{C} \text { and } \mathrm{K} \text {, folic } \\
\text { acid, thiamine and amino acids, close to or } \\
\text { during administration of the medicines }\end{array}$ & 10 \\
\hline Diclofenac & Foods in general & $\begin{array}{c}\text { Decrease risk of lesion in the } \mathrm{Gl} \\
\text { tract }\end{array}$ & $\begin{array}{l}\text { To take with foods to decrease risk of gastric } \\
\text { mucosa lesion }\end{array}$ & 2 \\
\hline Paracetamol & Carrot and lettuce (fibers) & Decrease absorption of the drug & $\begin{array}{l}\text { To avoid foods rich in fibers close to or during } \\
\text { administration of the drug }\end{array}$ & 1 \\
\hline \multicolumn{5}{|l|}{ Diuretic } \\
\hline Spironolactone & Milk and meat (potassium) & Retains potassium (K) & To avoid administration with foods rich in $\mathrm{K}$ & 8 \\
\hline Furosemide & Pumpkin, rice, carrot, meat (sodium) & Deplete sodium ( $\mathrm{Na}$ ) & To avoid administration with foods rich in $\mathrm{Na}$ & 2 \\
\hline \multirow[t]{2}{*}{ Hydrochlorothiazide } & \multirow[t]{2}{*}{ Cheese, fried egg and meat } & \multirow{2}{*}{$\begin{array}{l}\text { Increase absorption of the drug and } \\
\text { deplete sodium }\end{array}$} & To administer with fatty foods & \multirow[t]{2}{*}{1} \\
\hline & & & To avoid administration with foods rich in $\mathrm{Na}$ & \\
\hline \multicolumn{5}{|l|}{ Anti-ulcer } \\
\hline Aluminum hydroxide & Meat and beans (iron) & Deplete absorption of iron (Fe). & $\begin{array}{l}\text { Do not eat foods with Fe close to or during } \\
\text { administration of the drug }\end{array}$ & 1 \\
\hline Omeprazole & Chicken and milk (vitamin B12) & Deplete absorption of vitamin B12 & $\begin{array}{l}\text { Do not eat foods rich in vitamin B12 close to or } \\
\text { during administration of the drug }\end{array}$ & 1 \\
\hline Ranitidine & Milk and meat (vitamin B12) & Deplete absorption of vitamin B12 & $\begin{array}{l}\text { Do not eat foods rich in vitamin B12 close to or } \\
\text { during administration of the drug }\end{array}$ & 1 \\
\hline \multicolumn{5}{|l|}{ Laxatives } \\
\hline Mineral oil & $\begin{array}{l}\text { Pumpkin (vitamin A) and vegetable } \\
\text { salad (vitamin K) }\end{array}$ & $\begin{array}{l}\text { Deplete absorption of vitamins A } \\
\text { and K }\end{array}$ & $\begin{array}{l}\text { Do not eat foods rich in vitamins A, D, E and K } \\
\text { close to or during administration of the drug }\end{array}$ & 1 \\
\hline
\end{tabular}

were mulatto, black and white, respectively. A total of $25 \%$ of patients were smokers and the main reason for hospital admission was systemic arterial hypertension $(22 \%)$. Other reasons included wounds in left upper limb, gastric ulcer, gastritis, apnea, cirrhosis, intestinal infection, stroke, fever, burns, pneumonia, abdominal pain, thrombosis, renal problems and diarrhea.

Most patientswere married or lived in a stable marital situation (72\%). Concerning the type of household, $32(82 \%)$ had their own home. As to schooling level, most were illiterate $(58.97 \%)$. Eighteen patients were farm workers $(46 \%)$ and 22 had a family income of one minimum salary $(56 \%)$. A total of $33(15 \%)$ patients were alcoholic.

The average number of medications prescribed to inpatients at the HRJL and followed-up by the study was 1.36; in that, 25 drugs were administered in the morning, 29 in the afternoon, 21 in the evening and 7 during the night.

Of 82 drugs prescribed in all periods, $16(19.5 \%)$ could present interaction with food, totaling up 60 possible interactions between nutrients/foods and medications. Thus, the following possible interactions were identified: $18(30 \%)$ with captopril (cardiovascular drug), 10 (17\%) with acetylsalicylic acid (antiinflammatory drug) and $8(13 \%)$ with spironolactone (diuretic), which were the most frequent among the drug classes investigated. Moreover, in the interactions detected, $32(53 \%)$ accounted for cardiovascular medications, $13(22 \%)$ for anti-inflammatory drugs, 11 $(18 \%)$ for diuretics and $4(7 \%)$ with drugs acting in the digestive system (Table 1).

\section{DISCUSSION}

The patients admitted to the HRJL receive diet and drugs appropriate to each case. Nonetheless, there is a huge demand of patients and care is standardized, so in most cases the possible interactions between food served and medications administered are not taken into account $^{(4,9)}$. These interactions can hinder the action of the medication and/or food, leading to increased use 
of drugs in chronic treatment and to malnutrition and worsening the clinical picture of patients.

The risks of possible food/drug interactions are greater in chronic treatments, and high doses of drugs can trigger such interactions. Moreover, elderly or malnourished patients are more susceptible to these possible interactions, for impaired metabolism and excretion of drugs associated to reduced absorption of nutrients in the elderly, and because of interference in the drug distribution process in the body of those presenting malnutrition ${ }^{(4,10)}$.

In the analysis of the records, males prevailed in frequency of possible food/drug interactions and most patients were aged over 41 years. The higher frequency of possible interactions in charts of elderly individuals, who are at greater risk, is corroborated by the literature ${ }^{(11-13)}$.

The consumption of foods with medications can have a significant effect on rate and extension of absorption. Three basic reasons are given to administer medications with meals: to increase drug absorption; to reduce the irritating effect of some medicines on the gastrointestinal mucosa; and to help in treatment compliance, by associating the medication to a relatively fixed activity, such as the main meals ${ }^{(11-14)}$.

The medications administered per os should be absorbed through the gastric mucosa and small bowel. In some cases, foods/nutrients or drugs can reduce the absorption of the other medication. In this study, for instance, the antihypertensive agent (captopril), identified as one of the main drugs in possible interactions with foods/nutrients, is not appropriately absorbed when administered close to or during meals; hence, it is recommended to be given one hour before or two hours after meals ${ }^{(15)}$. The present study suggests closer monitoring of inpatients by healthcare professionals during prescription and/or administration of medications. In addition, patients on treatment of chronic disease should be oriented about these pharmacological issues in order to minimize adverse reactions and drug interactions (drug/drug and food/drug).

The possible interaction between acetylsalicylic acid (ASA) and vitamin C was often detected in the records analyzed. Some studies showed that ASA reduces absorption and increases excretion of vitamin $\mathrm{C}$, since there is a decreased uptake by tissues and a significant drop in vitamin reserve in platelets ${ }^{(5)}$.

ASA also leads to depletion of body reserves of vitamin $\mathrm{K}$ and increases the renal excretion of thiamine, folic acid and amino acids ${ }^{(4)}$. Therefore, ASA should be administered one hour before or two hours after meals of patients, with foods rich in folic acid, thiamine, and vitamins $\mathrm{C}$ and $\mathrm{K}$. If given close to or during meals, ASA will increase the excretion of these nutrients.
Another possible interaction often observed in charts was between the diuretic (spironolactone) and foods rich in potassium (K), milk and meats. Some studies indicate that spironolactone retains $\mathrm{K}^{(15)}$, thus, it is recommended to avoid administering of this drug with foods rich in potassium.

The literature suggests a pharmaceutical monitoring of patients during prescription and administration of medications, giving specific orientations about treatment, such as to avoid foods one hour before or some hours after taking a medicine, or taking drugs at intervals of at least two hours after meals. This important precaution minimizes many interactions between foods/nutrients and medications. There are studies demonstrating that the administration of laxatives during meals produce interactions with foods/nutrients, leading to deficiency of carotene and fat-soluble vitamins $(\mathrm{A}, \mathrm{D}, \mathrm{E} \text { and } \mathrm{K})^{(4)}$.

The present study found possible interactions between emollients, such as mineral oil, and nutrients of the patients' diet. The literature reports these drugs decrease absorption of fat-soluble vitamins ${ }^{(4)}$. Therefore, it is recommended to give the medication one hour before or two hours after meals, providing foods rich in vitamins $\mathrm{A}, \mathrm{D}, \mathrm{E}$ and $\mathrm{K}$, to avoid inappropriate or deficient absorption of such nutrients.

As to the possible interactions between foods/nutrients and anti-ulcer agents, omeprazole or ranitidine relate to foods rich in vitamin $\mathrm{B}_{12}$ (meat, chicken and milk), and the investigations showed that these drugs deplete absorption of this nutrient. Hence, patients should not receive foods rich in vitamin $B_{12}$ close to or during administration of these medicines ${ }^{(5)}$. Another interaction that may occur is between aluminum hydroxide and iron-rich foods (meat and beans). This drug should be given one hour before or two hours after meals of patients with foods rich in vitamin $\mathrm{B}_{12}$, to avoid reduced absorption.

\section{CONCLUSIONS}

The results showed that there are many possible interactions between foods/nutrients and drugs during medical treatment of inpatients due to interference in the pharmacokinetic processes of medications, which may lead to nutritional deficiencies for reduced absorption and/ or increased excretion of several nutrients. Furthermore, they indicate a possible risk factor for longer hospital stay, higher cost of treatment and nutritional deficiencies impairing patient's recovery.

These data showed that the multidisciplinary team work, including physicians, pharmacists, nurses and dietitians could contribute very much to prevent, detect and solve the possible interactions between foods/nutrients and drugs, and consequently to improving quality of life of patients. 


\section{REFERENCES}

1. Barndregt K, Soeters R. Suporte nutricional. In: Gibney MJ, Elia M, Ljuncqvist 0, Dowsett JJ. Nutrição clínica. Rio de Janeiro: Guanabara Koogan; 2007.

2. Gassul MA, Cabré E. 0 trato gastrointestinal. In: Gibney MJ, Elia M, Ljuncqvist 0, Dowsett JJ. Nutrição clínica. Rio de Janeiro: Guanabara Koogan; 2007.

3. Farhat FC, Iftoda DM, dos Santos PH. Interações entre hipoglicemiantes orais e alimentos. Saúde Rev. 2007;9(21):57-62.

4. Gomez R, Venturini CD. Interação entre alimentos e medicamentos. Porto Alegre: Letra e Vida; 2009.

5. Schweigert ID, Plestch MU, Dallepianne LB. Interação medicamento-nutriente na prática clínica. Rev Bras Nutr Clín. 2008;23(1):72-7.

6. Domingues CG, Paraná SP. Interações dos medicamentos com as refeições servidas na clínica de cirurgia urológica do hospital de clínicas UFPR. RUBS. 2005;1(4 Supl 1):31-2.

7. Pronsky ZM, Fada SR, Crowe JP, Pharmd RPH. Interações entre alimentos e drogas. In: Mahan LK, Escott-Stump S. Alimentos, nutrição e dietoterapia. 11a ed. São Paulo: Roca; 2005. Capítulo 19.
8. Cipolle RJ, Strand, LM, Morley PC, Frakes M. Resultados del ejercicio de la atención farmacéutica. Pharmaceutical Care España. 2000;(2):94-106.

9. Gil Esparza AM. Interacciones alimento-medicamento y autocuidado. Alimentaria. 1997;35(282):19-25.

10. Dantas SC. Guia farmacoterapêutico/Hospital de Messejana Dr. Carlos Alberto Studart Gomes. Fortaleza: UECE; 2009.

11. Moura MR, Reyes FG. Interação fármaco-nutriente: uma revisão. Rev Nutr; 2002;15(2):223-38.

12. Magedanz L, Jacoby T, da Silva D, dos Santos L, Martinbiancho J, Zuchermann J. Implementação de um programa para evitar possíveis interações fármacoalimento em pacientes adultos internados em unidades clínicas e cirúrgicas de um hospital universitário. Rev HCPA. 2009;29(1):29-32.

13. Maka DA, Murphy LK. Drug-nutrient interactions: a review. AACN Clin Isssues. 2000;11(4)580-9.

14. Kirk JK. Significant drug-nutrient interactions. Am Fam Physician. 1955;51(5):1175-82.

15. Lourenço R. Enteral feeding: drug/nutrient interaction. Clin Nutr. 2001;20(2):187-93. 